\title{
Biological Attributes of Unfermented and Fermented Oat Milk Compared to Cow Milk in Alloxan-Induced Diabetic Rats Safaa T. Gohari ${ }^{1}$; O. I. El-Batawy ${ }^{2 *}$ and Samar M. Mahdy ${ }^{2}$ \\ ${ }^{1}$ Home Economic Dept., Faculty of Specific Education, Ain Shams Univ., Cairo, Egypt \\ ${ }^{2}$ Food Science Dept., Fac. of Agric., Ain Shams Univ., Shoubra Khaima, 11241, Cairo, Egypt. \\ *E-mail:samoelbatawy@hotmail.com
}

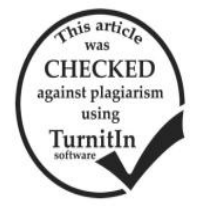

\section{ABSTRACT}

The present study aimed to assess the therapeutic effect of the unfermented and fermented cow; oat milk (CM, OM, FCM, and FOM) and fermented oat milk supplemented with $2 \%$ whey protein concentrate (FOM+WP) in diabetic rats. Alloxan was applied for inducing diabetes and hyperlipidemia in rats. The rats were randomly divided into two main groups. Control (-) (6 rats) were fed on a standard diet, while the second group (42 diabetics rats) were divided into six groups (6 rats each), and treated by different unfermented and fermented milk types by epigastric tube for 4 weeks. After four weeks, all treatments reduced the level of glucose, the serum levels of TC, TG and LDL-c compared to control $(+)$ group and this was associated with a significant increase ( $<<0.05)$ in HDL-c in these groups. The highest significantly $(\mathrm{p}<0.05)$ decrease recorded in the groups fed with $(\mathrm{OM})$ and $(\mathrm{FCM})$, respectively. Liver enzymes activity decreased significantly $(\mathrm{P}<0.05)$ in FOM + WP, FOM, FCM and OM groups, respectively. Feeding the rats on fermented oat milk fortified with whey protein led to decrease the fecal total anaerobes and fecal enterobacterial counts and stimulate the viability of both fecal lactobacilli and bifidobacteria in the intestinal colon, compared with other treatments. Histopathological examination of the liver sections showed no histopathological alteration in the hepatic parenchyma in (FOM+WP) group. (OM) and (FCM) groups showed no histopathological alteration and the islands of Langerhans cells were in normal size as well as the surrounding acini and ducts. In conclusion, treatment with oat milk led to curing hyperglycemia and hyperlipidemia in diabetic rats. Meanwhile, treatment with fermented oat milk fortified with whey proteins resulted in a better effect on the liver and improved the growth of the health-promoting intestinal microflora.

Keywords: Diabetes, Alloxan, Hyperlipidemia, Hypercholesterolemia, Fermented oat milk.

\section{INTRODUCTION}

Diabetes mellitus (DM) is epidemic disease suffusion around the world. The global prevalence of the disease is expected to increase from $2.8 \%$ in 2000 to $4.4 \%$ in 2030 (Peschke, 2007, Yajing et al., 2012 and Shehata and Moussa, 2014).

The $\beta$-cell toxin (alloxan,) is a model substance in type 1 diabetes. Alloxan resulted in ROS. During this redox reaction, free radicals are formed which results in the beta cell toxic action of alloxan (Tyrberg et al. 2001 and Lenzen, 2008).

There is a significant relationship between diabetes and lipid profile abnormalities which may induce a high risk of cardiovascular diseases (Lukic et al., 2014 and Sangwan and Singh, 2018).

Numerous drugs and treatments to diabetes and lower cholesterol concentration have been successfully used but there were many adverse effects associated with synthetic medicine. Oat is effective in relieving the effects of high blood pressure, resulting in lower total serum, and LDL cholesterol, regulation of glucose and insulin levels in the blood, weight control and enhanced gastrointestinal health. Many of these effects are attributed to the presence of dietary fiber, primarily $\beta$-glucans. $\beta$-glucansare known to show the hypocholesterolemic effect. An increase in bowel viscosity is critical to lowering cholesterol. Concentration, structure, and molecular weight, play important roles in $\beta$ glucan functionality. $\beta$-glucans decreased serum total cholesterol (18.9\%) and LDL-cholesterol (24.3\%) in Sprague-Dawley rats. Addition of $\beta$-glucan resulted in increased bile acid secretion (Bekers et al., 2001, Lambo et al., 2005, Baroutkoub et al., 2010, Bruckert, 2006 Yang et al., 2003, Ibrugger et al., 2013, Ahmed et al., 2017,and Grundy et al., (2018)).

Probiotics in functional fermented food can improve patient's conditions in medical disorders such as cancer, liver disease, genitourinary tract infections, atopic disease, and infections with Helicobacter pylori. Also, inflammatory intestinal diseases like Crohn's disease and Allergy, ulcerative colitis irritable bowel syndrome, diarrhea, hypercholesterolemia and others; all such findings have been supported by several studied demonstrating improved results using fermented food containing probiotics (Saikali et al., 2004 , Sheth, and Garcia-Tsao, 2008, Reid et al., 2001, Kalliomäki et al., 2001, Felley et al., 2001, Furrie et al., 2005, Prantera et al., 2002, and Bibiloni et al., 2005, Fanigliulo et al., 2006, Allen et al., 2010 and Sudha et al., 2009)Probiotics have antidiabetic and antihypertensive

properties by modulating lipid profile and insulin resistance.. Oat is shown as a suitable substrate for various types of lactic acid bacteria and functional fermented products could be improved by the production of oat-based milk or cow-oat milk mixtures (FAO/WHO, 2002; Fernandez-Garcia et al., 1998; Bekers et al., St-Onge et al., 2001, ,Martensson et al., 2001 and Lye et al., 2009).

Therefore, the recent study aimed to detect the probable anti-diabetic and hypolipidemic effects of unfermented and fermented oat milk compared to cow milk in alloxan-induced diabetic rats. As well as, their abilities to activate the growth of the health-promoting intestinal microflora, with a particular stress on Bifidobacteria and lactic acid bacteria genus.

\section{MATERIALS AND METHODS}

Fresh cow's milk was obtained from Faculty of Agriculture, Cairo University, Cairo, Egypt. Skim milk powder (SMP) (97\% DM). Dried whey protein concentrate (DWPC) was purchased from Mullins Whey Company, USA origin. The chemical composition of DWPC was $95.23,2.74,87.21$ and $0.25 \%$ for dry matter, ash, protein and acidity contents, respectively. Oat flakes purchased from local market. $\alpha$-amylase obtained Sigma Aldrich which had an activity of $2000 \mathrm{IU}$ in a powder form.

\section{Bacterial starter cultures}

The bacterial culture used in this study, ABT-3 DIP $50 \mathrm{u}$ consists of Lactobacillus acidophilus, 
Streptococcus thermophilus and Bifidobacterium bifidium obtained from Chr. Hansens Laboratories., Denmark and prepared by adding $1.2 \%$ of lyophilized cell culture into $11 \%$ sterilized reconstituted skim milk powder and incubated at $39^{\circ} \mathrm{C}$ for $5 \mathrm{hr}$ before $24 \mathrm{hr}$.

Preparation of oat milk sample:

Oat milk was prepared by Deswal et al., (2014).

Making of fermented milk samples:

Three experimental fermented milk samples, (labeled as FCM, FOM and FOM+DWPC) were made from cow milk fortified with $2 \%$ skim milk powder, oat milk and oat milk fortified with $2 \%$ dried whey protein concentrate, respectively. All milk samples were heated at $90^{\circ} \mathrm{C}$ for 10 min and subsequently cooled to $40^{\circ} \mathrm{C}$ and inoculated with 3\% ABT-3 starter culture (Streptococcus thermophilus, Lactobacillus acidophilus and Bifidobacterium bifidium. All samples were aseptically transferred into $100 \mathrm{ml}$ plastic containers. Inoculated cow milk samples were incubated at $39^{\circ} \mathrm{C}$ till coagulation ( $\mathrm{pH} 4.6$ ) then cooled to $4^{\circ} \mathrm{C}$. However, different inoculated oat milk samples were incubated at $39^{\circ} \mathrm{C}$ for $16 \mathrm{hrs}$. The resulting fermented samples were stored at $4^{\circ} \mathrm{C}$ for 21 days. Samples were taken when fresh, and after 3, 7,14 and 21 days at $5^{\circ} \mathrm{C}$ for analyses.

Evaluation of the biological attributes of different unfermented and fermented milk types:

Animal, housing and diets:

Forty-two male Albino rats weighing about $150 \pm 20$ $\mathrm{g}$ were obtained from ARC. The animal groups were filtered under atmospheric condition. Pathogen-free water and air, and maintained at a temperature between $20-25^{\circ} \mathrm{C}$ for
8 weeks with a $12 \mathrm{~h}$ light/dark cycle and light cycle (8-20 h) and relative humidity of $50 \%$. The animals acclimatized for one week as an adaptation period. The animals were randomly divided into 2 groups. The first group of rats control (-) (6 rats) was fed on standard diet, while the second group (42 rats) were fast 24 hours, injected with prepared alloxan using citrate buffer $0.1 \mathrm{M}(\mathrm{pH}=4.6)$ as vehicle, at a dose of $150 \mathrm{mg}$ alloxan/kg body weight (Szkudelski, 2001).At the third day, alloxan injection was carried out, blood glucose was examined and animals with glucose concentration higher than $200 \mathrm{mg} / \mathrm{dl}$ were considered as diabetic rats. Then rats were divided into six groups and treated by different unfermented and fermented milk types by epigastric tube as seen in Table(1) for 4 weeks. The rats were weighed weekly and at the end of the experimental feeding period, the animals were fasted overnight, anesthetized with ether and sacrificed for analysis.

The followed steps mentioned were done in 6 rats after 4 weeks of treatment in each group:

1- Fasting animals for 12 hours, 2- samples of blood were withdrawn from orbital plexus venous, 3- Samples of blood were allowed to clot, 4- serum of blood was obtained by centrifugation at $3500 \mathrm{rpm}$ for $10 \mathrm{~min}$ at $4^{\circ} \mathrm{C}$., 5- freezing the serum at $-18^{\circ} \mathrm{C}$ until analyzed, 6anesthetizing the animals with ether and sacrificed, 7quickly dissecting the animals to excise the liver, kidney, testes, heart, and spleen and 8-weighing these organs and keeping them in $10 \%$ formaldehyde until histological investigations (Schermer and Chermer, (1967)

Table 1. Experimental diets of rats used in the biological study.

\begin{tabular}{lc}
\hline Groups & Experimental diets \\
\hline Control $(-)$ & basal diet $(-)$ \\
Control $(+)$ & $*$ Alloxan $($ control +$)+$ Standard diet \\
CM & $*$ Alloxan + Standard diet $+(5 \mathrm{ml}$ cow milk by epi gastric tube $)$ \\
FCM & $*$ Alloxan + Standard diet $+(5 \mathrm{ml}$ fermented cow milk by epi gastric tube $)$ \\
OM & $*$ Alloxan + Standard diet $+(5 \mathrm{ml}$ oat milk by epi gastric tube $)$ \\
FOM & $*$ Alloxan + Standard diet $+(5 \mathrm{ml}$ fermented oat milk by epi gastric tube $)$ \\
FOM+WP & $*$ Alloxan + Standard diet $+(5 \mathrm{ml}$ fermented oat milk and whey protein by epi gastric tube $)$ \\
\hline
\end{tabular}

*intraperitoneal injection

\section{Biological Determination:}

Biological evaluation of the various examined diets according to Chapman et al., (1959).

\section{Serum biochemical Analyses:}

Blood glucose level was estimated as described by . Serum total cholesterol was determined colorimetrically at $500 \mathrm{~nm}$. serum triglycerides was determined at $505 \mathrm{~nm} \mathrm{~b}$, HDL-c(High-density lipoprotein) cholesterol was determined at $500 \mathrm{~nm}$ by, and LDL-c (Low-density lipoprotein) cholesterol were determined at $500 \mathrm{~nm}$ as described by (Allain et al. 1974, Trinder, Allain et al. 1974, 1969 Fassati and prencipe, 1982 and Wieland and Seidel, 1983).

\section{Determination of liver enzymes:}

The determination of liver enzymes described by Sherwin, (1984).

\section{Histopathology technique}

The tissues of the liver and kidney were fixed immediately after dissection in $10 \%$ neutral formalin for 24 h. according to Bancroft and Stevens, (1996).

\section{Fecal microbiological analysis:}

Rat faces were collected every week in sterile Petri dishes and immediately subjected to microbiological analysis. Serial dilutions of feces were prepared according to Guerin- Danan and Andrieux, (1998) in pre-reduced liquid casein yeast medium. Total anaerobic bacteria and enterobacteria were counted in brain heart infusion agar (BHI) and Desoxycholate agar (DCA) medium, respectively. Lactobacilli count was determined using Man Rogosa and Sharpe (MRS) agar media according to De Man et al., (1960). Bifidobacteria spp. was counted on Beerens agar media according to Beerens, (1990).

Statistical analysis:

Statistical analysis was performed according to SAS, (1999).

\section{RESULTS AND DISCUSSION}

Biological evaluation of alloxan-induced diabetic rats supplemented with different unfermented/fermented cow and oat milk samples:

General signs in the rats:

No rats in among groups died during the experimental period (4 weeks) and some of the rats in groups exhibited abnormal signs throughout the test period. The weights of the various organs/body weight $\%$ of the 
rats treated by different fermented cow and oat milk samples are shown in Table (2). The liver/body weight ratio significantly increased in rats injected by alloxan, compared with the control (-) group. These increases could be attributed to the accumulation of cholesterol in the liver (Jemai et al., 2008). A significant decrease $(\mathrm{P} \leq 0.05)$ could be observed in the weight of liver in the treatment groups (FOM+WP, FOM, FCM, OM, and CM), respectively compared with control $(+)$ group. These results agree with those shown in Table (4), which resulted in higher significant of liver enzyme (ALT and AST) in control $(+)$ group, and histopathology examination which illustrates liver damage.

Table 2. Effect of different unfermented/fermented cow and oat milk samples on organs weight of alloxan-induced diabetic rats.

\begin{tabular}{lcc}
\hline \multirow{2}{*}{ Groups } & \multicolumn{2}{c}{ Mean \pm SE of Organs Weight } \\
\cline { 2 - 3 } & Liver & Pancreas \\
\hline Control (-) & $2.60^{\mathrm{c}} \pm 1.00$ & $0.17^{\mathrm{a}} \pm 1.68$ \\
Control (+) & $4.04^{\mathrm{a}} \pm 1.08$ & $0.09^{\mathrm{b}} \pm 0.65$ \\
CM & $3.58^{\mathrm{b}} \pm 1.64$ & $0.14^{\mathrm{a}} \pm 1.42$ \\
FCM & $2.98^{\mathrm{c}} \pm 1.75$ & $0.17^{\mathrm{a}} \pm 1.72$ \\
OM & $3.02^{\mathrm{c}} \pm 0.72$ & $0.17^{\mathrm{a}} \pm 1.75$ \\
FOM & $2.86^{\mathrm{c}} \pm 1.51$ & $0.13^{\mathrm{ab}} \pm 1.06$ \\
FOM + WP & $2.74^{\mathrm{c}} \pm 1.66$ & $0.14^{\mathrm{ab}} \pm 1.50$ \\
\hline
\end{tabular}

Data are presented as means \pm SE $(n=6)$. Data in a column with different superscript letters are statistically different $(P \leq 0.05)$.

On the contrary, the pancreas /body weight ratio significantly decreased in rats injected by alloxan compared with the control (-) group, after feeding on all groups by different fermented cow and oat milk samples. It could also be observed an increase in the pancreas /body weight ratio in the treatment groups (OM , FCM, FOM+WP, CM and FOM), respectively, compared with control $(+)$ group. These results agree with the data shown in figure (1).

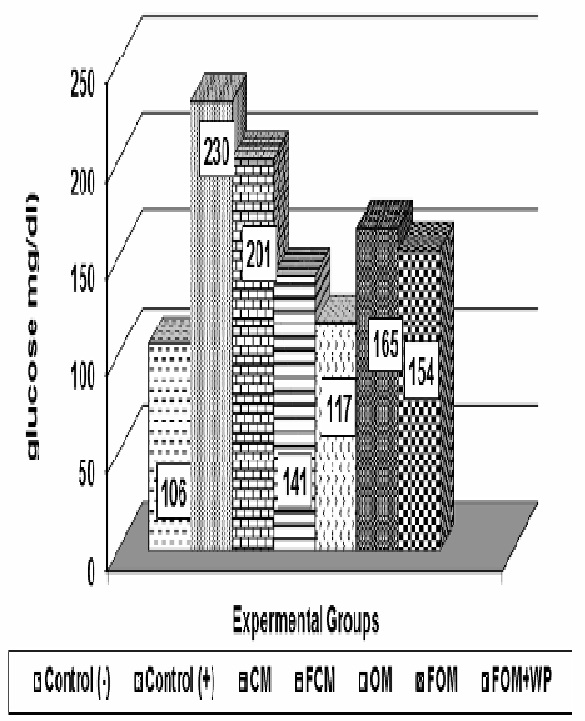

Fig. 1. Serum blood glucose concentration $(\mathrm{mg} / \mathrm{dl})$ in alloxan-induced diabetic rats treated with different unfermented and fermented milk types.

\section{Biochemical Analyses:}

Serum biochemical Analyses:

The effects of feeding fermented cow milk and fermented oat milk on glucose level in rats are shown in (Fig.1). It could be seen highly increase $(\mathrm{P} \leq 0.05)$ in the level of glucose $(230 \mathrm{mg} / \mathrm{dl})$ of control $(+)$ group, treated with a single dose of alloxan, compared to control (-) group (106 mg/dl), which agrees with Radhika et al., (2011). After four weeks of administration of OM, FCM, FOM + WP, FOM and CM reduce the level of glucose to 117,141 , 154, 156 and $201 \mathrm{mg} / \mathrm{dl}$, respectively., The highest decrease in glucose concentration was observed in the animal groups treated by alloxan and fed with (OM) and (FCM). Little concentrations of $\beta$-glucans in oats) was. The viscosity of $\beta$-d-glucan plays an important role in postprandial hyperglycemia and insulin responses (Tosh, 2013, Jenkins et al., 2002 and Tomimatsu and Horie, 2005; Shori \& Baba, 2011; Regand et al.and Dong et al. 2011; Batista et al., 2015 and Pei et al., 2017). Certain chain fatty acids in fermented milk have anti-diabetic proved the hypoglycemic effect of yogurt. This was attributed to its inhibitory effect on $\alpha$-glucosidase in milk.

Insulin deficiency as a result of diabetes leads to abnormalities in lipid metabolism (Arkkila et al., 2001 Balku et al., 2004). Alloxan-induced diabetic rats in the present studies showed a markly increase $\mathrm{P}<0.05$ in total triglycerides (TG) ,low-density lipoprotein (LDL-c) and total cholesterol (TC) of the diabetic group were detected, compared with control (-) group. While HDL-c decreased significantly $\mathrm{P}<0.05$ as compared to control (-) group (Table 3). This increase in TG might be due to the shortage of insulin under diabetic condition. The obtained result came in agreement with those of Arkkila et al. 2001, Hassan \& Emam, 2012 and Isa et al., (2013). These results are in agreement with previous reports (Hassan \& Emam, 2012; and Isa et al., 2013) and in the data presented in figure (1).

Table 3. Effect of different unfermented/fermented cow and oat milk samples on serum Lipid Profile (mg/dL) of alloxan-induced diabetic rats

\begin{tabular}{|c|c|c|c|c|}
\hline \multirow[b]{2}{*}{ Groups } & \multicolumn{4}{|c|}{ Parameters } \\
\hline & $\begin{array}{c}\text { TC } \\
(\mathrm{mg} / \mathrm{dL})\end{array}$ & $\begin{array}{l}\text { LDL-c } \\
\text { (mg/dL) }\end{array}$ & $\begin{array}{c}\text { HDL-c } \\
(\mathrm{mg} / \mathrm{dL})\end{array}$ & $\begin{array}{c}\text { TG } \\
(\mathrm{mg} / \mathrm{dL})\end{array}$ \\
\hline Control (-) & $93.67^{\mathrm{dd}} \pm 1.37$ & $40.33^{c} \pm 0.0$ & $52.00^{b} \pm 1.40$ & $49.67^{b c} \pm 0.06$ \\
\hline Control $(+)$ & $155.33^{\mathrm{a}} \pm 1.37$ & $76.00^{\mathrm{a}} \pm 1.2$ & $27.00^{\mathrm{d}} \pm 0.71$ & $89.33^{\mathrm{a}} \pm 0.14$ \\
\hline $\mathrm{CM}$ & $105.00^{\mathrm{bc}} \pm 0.01$ & $55.00^{\mathrm{bc}} \pm 0.0$ & $38.33^{\mathrm{c}} \pm 1.28$ & $60.67^{\mathrm{b}} \pm 1.04$ \\
\hline FCM & $96.66^{\mathrm{cd}} \pm 0.94$ & $47.67^{\mathrm{c}} \pm 0.4$ & $68.00^{\mathrm{a}} \pm 1.39$ & $35.00^{\mathrm{cd}} \pm 1.40$ \\
\hline $\mathrm{OM}$ & $90.33^{\mathrm{d}} \pm 1.33$ & $41.33^{\mathrm{c}} \pm 0.1$ & $60.33^{\mathrm{a}} \pm 0.12$ & $32.33^{\mathrm{d}} \pm 1.26$ \\
\hline FOM & $115.33^{\mathrm{b}} \pm 0.71$ & $66.33^{\mathrm{ab}} \pm 0.5$ & $45.33^{\mathrm{bc}} \pm 0.9$ & $50.00^{\mathrm{bc}} \pm 0.31$ \\
\hline FOM+WP & $100.33^{\mathrm{cd}} \pm 1.41$ & $56.33^{\mathrm{bc}} \pm 1$. & $8.67^{b} \pm 1.01$ & $54.33^{\mathrm{b}} \pm 0.43$ \\
\hline
\end{tabular}

Data are presented as means \pm SE $(n=6)$. Data in a column with different superscript letters are statistically different $(P \leq 0.05)$.

LDL-C: Low density lipoproteins cholesterol; LDL-C: Serum low density lipoproteins cholesterol; TC: Serum total cholesterol; TG: Serum triglyceride.

The present study showed that consumption of different unfermented and fermented milk types reversed the effects of alloxan by reducing the serum levels of TC, TG and LDL-c as compared with control $(+)$ group and this was associated with a significant increase $\mathrm{p}<0.05$ in HDL-c in these groups and therefore, reducing the risk for atherosclerosis. But, the highest significantly $\mathrm{p}<0.05$ 
decreased recorded at the groups affected by alloxan and fed with (OM) and (FCM) respectively.

The above hypolipidemic activity of oat milk might be due to the presence of $\beta$-glucan, which inhibits the lipid absorption can enhance fecal cholesterol and bile acid excretion (Tiwari and Cummins, 2011). In addition, $\beta$ glucanis suppresses the insulin secretion and thus halt the endogenous cholesterol synthesis. Furthermore, the lipid and protein contents in oat might also be responsible for the cholesterol-lowering activity. It could also be suggested that lipid and protein present in the oat could contribute to the hypocholesterolemic activity (Othman et al., 2011, Gunness and Gidley, 2014 and Othman et al., 2011).

The fermented milk administration resulted in an evident decrease of TG, TC, LDL-C, and increase of HDL$\mathrm{C}$ level, indicating that fermented milk alleviated the metabolic disorder of lipids. These results are consistent with previous studies. The cholesterol-lowering effect of probiotics up to a significant concentration of $22-33 \%$ and Lactobacillus rhamnosus GG also play an active role in lowering of cholesterol in mice as reported by (Pereira and Gibson, 2002, Liong and Shah, 2005, Begley et al., 2006, Kim et al., 2016).

Table 4. Effect of different unfermented/fermented cow and oat milk samples on Liver enzymes (mg/dl) of alloxan-induced diabetic rats.

\begin{tabular}{lcc}
\hline \multirow{2}{*}{ Groups } & \multicolumn{2}{c}{ Parameters } \\
\cline { 2 - 3 } & ALT(U/I) & AST(U/I) \\
\hline Control (-) & $26.33^{\mathrm{b}} \pm 0.71$ & $43.67^{\mathrm{b}} \pm 0.71$ \\
Control (+) & $48.33^{\mathrm{a}} \pm 0.12$ & $69.67^{\mathrm{a}} \pm 0.16$ \\
CM & $38.00^{\mathrm{ab}} \pm 0.46$ & $48.67^{\mathrm{b}} \pm 1.41$ \\
FCM & $35.00^{\mathrm{b}} \pm 1.22$ & $51.00^{\mathrm{b}} \pm 0.71$ \\
OM & $36.00^{\mathrm{b}} \pm 1.34$ & $57.00^{\mathrm{ab}} \pm 0.71$ \\
FOM & $31.00^{\mathrm{b}} \pm 1.02$ & $49.67^{\mathrm{b}} \pm 0.71$ \\
FOM+WP & $29.00^{\mathrm{b}} \pm 1.22$ & $47.33^{\mathrm{b}} \pm 1.36$ \\
\hline
\end{tabular}

Data are presented as means \pm SE $(n=6)$. Data in the same column with different superscript letters are statistically different $(P \leq 0.05)$.

Results in Table (4) indicated a remarkable decrease $(\mathrm{P} \leq 0.05)$ in serum ALT activity for all groups injected by alloxan and fed on different unfermented and fermented milk types as compared with the control group (-) 26.33 U/I, but (FOM + WP, FOM, FCM, and OM) groups recorded high significantly decreased $(\mathrm{P}<0.05)$, respectively as compared with the control $(+)$ group this results are consistent with Tameda et al., (2005). However, ALT is more specific for liver damage than AST. And AST recorded a significant decreased in all groups injected by alloxan and fed on different unfermented and fermented milk types as compared with the control group $(+)$ (69.67U/I) in the same Table (4).The death of hepatocytes liver usually results in the leakage of the enzymes in the affected tissue into the blood stream (Obi et al., 2001).

The increase in the activities of serum AST and ALT indicated that diabetes may have induced hepatic dysfunction, that liver cells were necrotized in the diabetic patient. noted that whey protein could decrease increased levels of AST and ALT in D-galactosamine-induced hepatitis in rats (Larcan et al., 1979 and Villani et al., 2005; Kume et al. 2006 and Pei et al., 2017).

\section{Microbiological analysis of faces:}

Since fecal flora populations reflect the microflora of the intestinal colon (Cummings and Macfarlane, 1991), therefore, rat's faces were collected and analyzed for flora analysis. As shown in Table (5), it could be noticed that, no significant differences in fecal total anaerobes and fecal enterobacterial counts were observed for rates feed on the basal diet (negative and positive control), unfermented cow and oat milk samples over the experimental period.

While, there were noticeable decreases in the fecal total anaerobes and fecal enterobacterial counts of rates received different unfermented and fermented milk types (FCM, FOM, and FOM+WP) through the first week and up to the end of the feeding period.

No significant differences in fecal lactobacilli counts of rats fed on the basal diet (negative and positive control) could be observed in unfermented cow and oat milk samples along the experimental period. It could also be seen that the rats received fermented oat milk fortified with whey protein had the highest count of fecal lactobacilli followed by group received unfortified fermented oat and cow milk samples along the experimental period respectively. The feces samples before the feeding trials did not exhibit the presence of bifidobacteria in case of the two control groups and that groups received unfermented cow and oat milk samples over the experimental period.

A significant increase in fecal bifidobacteria of rats receiving different fermented oat milk samples (FOM and FOM+WP) compared with rats received fermented cow milk. This is might be due to the high content of soluble and non-soluble fiber which makes oat a useful product to use in the prevention of different diseases, especially, those affecting the colon. B-glucans, the most prevalent oat soluble fiber, have prebiotic activity. B-glucans are seen to be able to stimulate the growth of the health-promoting intestinal microflora, with a particular effect on lactic acid bacteria and Bifidobacteria genus (Mattila-Sandholm et al., 2002; Roberfroid, 2002, Angelov et al., 2006 and SadiqButt et al., 2008).

Generally, feeding the rats on fermented oat milk fortified with whey protein led to stimulating the viability of both fecal lactobacilli and bifidobacteria in the intestinal colon compared with feeding on unfortified fermented oat milk. This is might be due to the whey protein to stimulate the probiotic bacteria in the intestinal tract. Whey proteins are rich in sulfur-containing amino acids, which are liberated during heat treatment. These amino acids containing sulfur reduce oxidative potential and favor the environment for the growth of probiotics (Mc-Comas and Gilliand, 2003). 
Table 5. Effect of feeding different unfermented and fermented milk types on the fecal microorganisms counts (log cfu/ml) in alloxan-induced diabetic rat's faces

\begin{tabular}{|c|c|c|c|c|c|}
\hline \multirow{2}{*}{ Treatment } & \multicolumn{5}{|c|}{ Feeding period (week) } \\
\hline & Initial count & 1 & 2 & 3 & 4 \\
\hline \multicolumn{6}{|c|}{ Fecal total anaerobes } \\
\hline Negative control & $9.65^{\mathrm{Aa}} \pm 0.70$ & $9.74^{\mathrm{Aa}} \pm 0.34$ & $9.81^{\mathrm{Aa}} \pm 0.65$ & $9.85^{\mathrm{Aa}} \pm 0.70$ & $9.87^{\mathrm{Aa}} \pm 0.12$ \\
\hline Positive control & $9.51^{\mathrm{Aa}} \pm 0.53$ & $9.73^{\mathrm{Aa}} \pm 0.62$ & $9.86^{\mathrm{Aa}} \pm 0.45$ & $9.90^{\mathrm{Aa}} \pm 0.54$ & $9.94^{\mathrm{Aa}} \pm 0.43$ \\
\hline $\mathrm{CM}$ & $9.63^{\mathrm{Aa}} \pm 0.48$ & $9.60^{\mathrm{Aa}} \pm 0.30$ & $9.57^{\mathrm{Aa}} \pm 0.35$ & $9.58^{\mathrm{Aa}} \pm 0.30$ & $9.65^{\mathrm{Aa}} \pm 0.61$ \\
\hline OM & $9.60^{\mathrm{Aa}} \pm 0.19$ & $9.54^{\mathrm{Aa}} \pm 0.43$ & $9.31^{\mathrm{Aab}} \pm 0.60$ & $9.11^{\mathrm{Bb}} \pm 0.45$ & $8.94^{\mathrm{Bb}} \pm 0.46$ \\
\hline $\mathrm{FCM}$ & $9.52^{\mathrm{Aa}} \pm 0.43$ & $8.93^{\mathrm{Bb}} \pm 0.47$ & $8.34^{\mathrm{Bc}} \pm 0.11$ & $7.81^{\mathrm{Cd}} \pm 0.20$ & $7.21^{\mathrm{Ce}} \pm 0.15$ \\
\hline FOM & $9.55^{\mathrm{Aa}} \pm 0.36$ & $8.90^{\mathrm{Bb}} \pm 0.11$ & $8.14^{\mathrm{Bc}} \pm 0.33$ & $7.64^{\mathrm{Cd}} \pm 0.10$ & $7.00^{\mathrm{Ce}} \pm 0.10$ \\
\hline $\mathrm{FOM}+\mathrm{WP}$ & $9.49^{\mathrm{Aa}} \pm 0.61$ & $8.91^{\mathrm{Bb}} \pm 0.38$ & $8.03^{\mathrm{Bc}} \pm 0.40$ & $7.59^{\mathrm{Cd}} \pm 0.08$ & $6.95^{\mathrm{Ce}} \pm 0.22$ \\
\hline \multicolumn{6}{|c|}{ Fecal enterobacteria } \\
\hline Negative control & $9.12^{\mathrm{Ac}} \pm 0.44$ & $9.57^{\mathrm{Ab}} \pm 0.45$ & $9.82^{\mathrm{Aa}} \pm 0.40$ & $9.87^{\mathrm{Aa}} \pm 0.40$ & $9.90^{\mathrm{Aa}} \pm 0.56$ \\
\hline Positive control & $9.20^{\mathrm{Ac}} \pm 0.50$ & $9.61^{\mathrm{Ab}} \pm 0.38$ & $9.92^{\mathrm{Aa}} \pm 0.30$ & $9.98^{\mathrm{Aa}} \pm 0.50$ & $10.11^{\mathrm{Aa}} \pm 0.60$ \\
\hline $\mathrm{CM}$ & $9.23^{\mathrm{Aa}} \pm 0.36$ & $9.31^{\mathrm{Aa}} \pm 0.40$ & $9.33^{\mathrm{Aa}} \pm 0.52$ & $9.35^{\mathrm{Aa}} \pm 0.28$ & $9.38^{\mathrm{Aa}} \pm 0.34$ \\
\hline OM & $9.21^{\mathrm{Aa}} \pm 0.50$ & $9.30^{\mathrm{Aa}} \pm 0.41$ & $9.34^{\mathrm{Aa}} \pm 0.20$ & $9.36^{\mathrm{Aa}} \pm 0.30$ & $9.38^{\mathrm{Aa}} \pm 0.37$ \\
\hline $\mathrm{FCM}$ & $9.16^{\mathrm{Aa}} \pm 0.36$ & $8.71^{\mathrm{Bb}} \pm 0.30$ & $7.90^{\mathrm{Bc}} \pm 0.14$ & $7.11^{\mathrm{Bd}} \pm 0.10$ & $6.42^{\mathrm{Be}} \pm 0.40$ \\
\hline FOM & $9.21^{\mathrm{Aa}} \pm 0.28$ & $8.64^{\mathrm{Bb}} \pm 0.18$ & $7.20^{\mathrm{Bc}} \pm 0.40$ & $6.70^{\mathrm{Cd}} \pm 0.15$ & $6.26^{\mathrm{Ce}} \pm 0.20$ \\
\hline$\underline{\mathrm{FOM}+\mathrm{WP}}$ & $9.15^{\mathrm{Aa}} \pm 0.35$ & $8.57^{\mathrm{Bb}} \pm 0.50$ & $7.11^{\mathrm{Bc}} \pm 0.36$ & $6.66^{\mathrm{Cd}} \pm 0.10$ & $6.10^{\mathrm{Ce}} \pm 0.10$ \\
\hline \multicolumn{6}{|l|}{ Fecal lactobacilli } \\
\hline Negative control & $7.04^{\mathrm{Aa}} \pm 0.15$ & $7.00^{\mathrm{ABa}} \pm 0.01$ & $6.98^{\mathrm{Ca}} \pm 0.10$ & $6.96^{\mathrm{Da}} \pm 0.09$ & $6.92^{\mathrm{Ea}} \pm 0.15$ \\
\hline Positive control & $6.96^{\mathrm{Aa}} \pm 0.25$ & $6.80^{\mathrm{Ba}} \pm 0.09$ & $6.66^{\mathrm{Cb}} \pm 0.15$ & $6.61^{\mathrm{Db}} \pm 0.07$ & $6.56^{\mathrm{Eb}} \pm 0.50$ \\
\hline $\mathrm{CM}$ & $7.11^{\mathrm{Ab}} \pm 0.48$ & $7.27^{\mathrm{Aa}} \pm 0.10$ & $7.31^{\mathrm{Ba}} \pm 0.31$ & $7.35^{\mathrm{Ca}} \pm 0.60$ & $7.41^{\mathrm{Da}} \pm 0.45$ \\
\hline OM & $7.27^{\mathrm{Ab}} \pm 0.20$ & $7.40^{\mathrm{Aa}} \pm 0.40$ & $7.44^{\mathrm{Ba}} \pm 0.30$ & $7.49^{\mathrm{Ba}} \pm 0.18$ & $7.52^{\mathrm{Da}} \pm 0.55$ \\
\hline FCM & $7.19^{\mathrm{Aac}} \pm 0.21$ & $7.37^{\mathrm{Ab}} \pm 0.56$ & $7.40^{\mathrm{Bb}} \pm 0.30$ & $7.55^{\mathrm{Bab}} \pm 0.14$ & $7.91^{\mathrm{Ca}} \pm 0.20$ \\
\hline FOM & $7.20^{\mathrm{Ad}} \pm 0.80$ & $7.66^{\mathrm{Ac}} \pm 0.25$ & $7.81^{\mathrm{Ab}} \pm 0.20$ & $7.93^{\mathrm{Aab}} \pm 0.44$ & $8.14^{\mathrm{Ba}} \pm 0.32$ \\
\hline FOM+WP & $7.21^{\mathrm{Ae}} \pm 0.20$ & $7.70^{\mathrm{Ad}_{ \pm}} \pm 0.08$ & $7.82^{\mathrm{Ac}} \pm 0.25$ & $8.11^{\mathrm{Ab}} \pm 0.70$ & $8.38^{\mathrm{Aa}} \pm 0.10$ \\
\hline \multicolumn{6}{|c|}{ Fecal bifidobacteria } \\
\hline Negative control & ND & ND & ND & ND & ND \\
\hline Positive control & ND & ND & ND & ND & ND \\
\hline $\mathrm{CM}$ & ND & ND & ND & ND & ND \\
\hline OM & ND & ND & ND & ND & ND \\
\hline FCM & ND & $4.31^{\mathrm{Cd}_{ \pm}} 0.01$ & $4.68^{\mathrm{Cc}} \pm 0.09$ & $5.03^{\mathrm{Cb}} \pm 0.15$ & $5.28^{\mathrm{Ba}} \pm 0.09$ \\
\hline FOM & ND & $5.06^{\mathrm{Bd}} \pm 0.01$ & $5.42^{\mathrm{Bc}} \pm 0.12$ & $6.17^{\mathrm{Bb}} \pm 0.20$ & $6.20^{\mathrm{Aa}} \pm 0.06$ \\
\hline FMO+WP & ND & $5.21^{\mathrm{Ad}} \pm 0.05$ & $5.63^{\mathrm{Ac}} \pm 0.10$ & $6.21^{\mathrm{Ab}} \pm 0.15$ & $6.35^{\mathrm{Aa}} \pm 0.08$ \\
\hline
\end{tabular}

abc Values (mean $\pm S E$; $n=6$ ) with different superscripts in a row are significantly different at the level of $P<0.05$.

${ }^{A B C}$ Values (mean $\pm S E ; n=6$ ) with different superscripts in a column are significantly different at the level of $P<0.05$.

\section{Histopathological Examination:}

Liver and pancreas were examined and the photomicrographs are illustrated in Figs. (2 and 3). Alloxan is diabetogenic chemical, pathological effects and toxic glucose analogs that preferentially accumulates in pancreatic beta cells via the glucose transporter 2 . The presence of intracellular thiols, especially, glutathione, alloxan generates reactive oxygen species in a cyclic redox reaction with its reduction product, dialuric acid. Autooxidation of dialuric acid generates superoxide radicals, hydrogen peroxide and, in a final iron-catalyzed reaction step, hydroxyl radicals. (Lenzen, 2008, and Minaiyan et al., 2011).

Histopathological examination of the liver sections from control - (normal rats fed on commercial diet only) showing no histopathological alteration and the normal histological structure of the central vein and surrounding hepatocytes in the parenchyma were recorded in (Fig.2A). In contrast, in the control $(+)$ group (normal rats fed on commercial diet + injection with alloxan) showing edema in the portal area, few inflammatory cells infiltration with dilatation and hyperplasia in the bile ducts as well as dilatation in the portal vein (Fig.2B).

There were dilatation and hyperplasia in the bile ducts in the portal area associated with dilatation in the central vein at the animal's group affected by alloxan plus fed on (CM) as seen in (Fig. 2C). While, in the animal's group affected by alloxan plus fed on (FCM) newly formed bile ductules were detected in the portal area (Fig. 2D).

On other hand, the liver of injected rat by alloxan fed on $(\mathrm{OM})$ showed congestion in the central vein as seen in (Fig.2E). Inflammatory cells infiltration was observed in a focal manner in the portal area associated with congestion in the portal vein at the animal's group affected by alloxan plus fed on (FOM) in (Fig.2F).In contrast, there was no histopathological alteration in the hepatic parenchyma as recorded in (Fig.2G) at the liver of injected rat by alloxan plus fed on (FOM+WP).

Pancreas

The rats fed on commercial diet only (control (-)) showing no histopathological alteration and the normal histological structure of the islands of Langerhans cells as the endocrine portion as well as the acini and duct system as exocrine one was recorded in (Fig.3A). Meanwhile, animals fed on commercial diet plus injection with alloxan (control $(+)$ ) observed atrophy with the absence of most of the cells of the islands of Langerhans in all of the lobules (Fig.3B). Furthermore, Pancreas of animals affected by alloxan plus fed on (CM)the cells of the islands of Langerhans were histologically intact while the blood vessels were dilated as well as the ducts (Fig.3C). In contrast, animals affected by alloxan and fed (OM) and (FCM) as seen in Fig.(3E and D) respectively, showing no 


\section{Safaa T. Gohari et al.}

histopathological alteration and the islands of Langerhans cells were in normal size as well as the surrounding acini and ducts. There was atrophy in the islands of Langerhans cells associated with eosinophilic casts formation in the duct lumen in the rats affected by alloxan plus fed on (FOM) and (FOM+WP) as recorded in Fig. ( $3 \mathrm{~F}$ and $\mathrm{G})$.
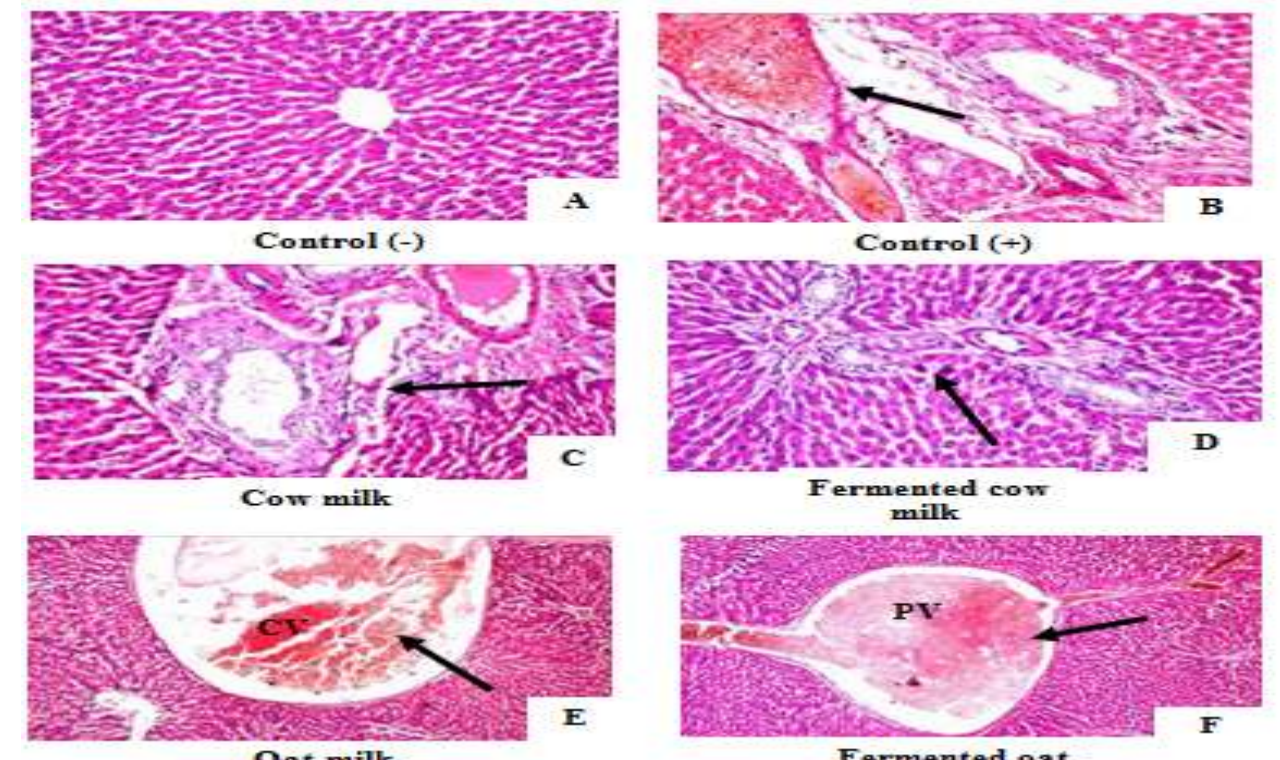

$$
\begin{gathered}
\text { Fermented oat } \\
\text { milk }
\end{gathered}
$$

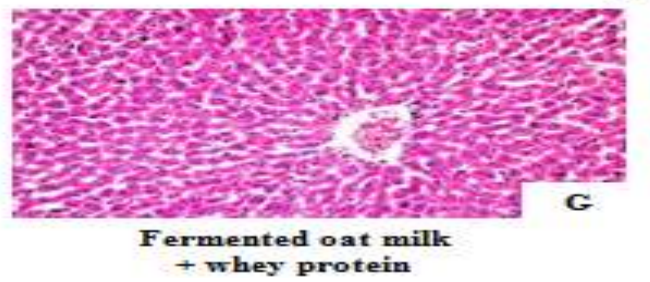

Fig. 2. Photomicrograph of sections of liver of different rats groups, stained with $\mathrm{H} \& \mathrm{E}, \mathrm{X} 400$ Liver
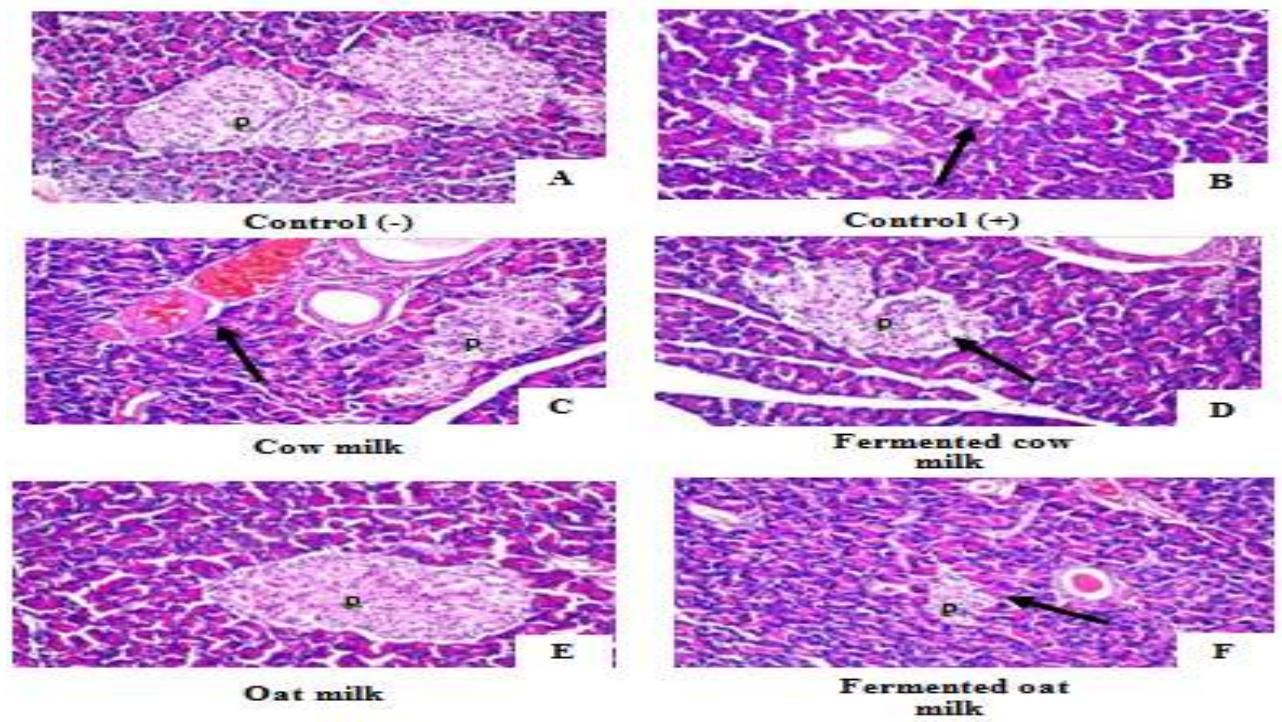

Oat milk

Fermented oat

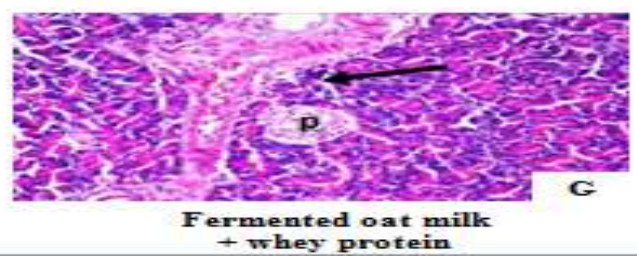

Fig. 3. Photomicrograph of Sections of Pancreas of different rats groups, stained with H \& E, X 400. 


\section{CONCLUSION}

Based on the aforementioned results, it could be concluded that consumption of oat milk and fermented oat milk products with "health-enhancing" properties as symbiotic and probiotics products play a major role in prevention as well as in treating some health problems such as diabetes, hypercholesterolemia, and hyperlipidemia. Feeding the rats on fermented oat milk fortified with whey protein has a better effect on the liver and led to stimulating the viability of both fecal lactobacilli and bifidobacteria in the intestinal colon.

\section{REFERENCES}

Ahmed, R.M., Elsanhoty, R.M., Al-Samanc, M.A. and Ramadan, M.F. (2017). Hypocholesterolaemic effect of probiotic yogurt enriched with barley $\beta$-glucan in rats fed on a high-cholesterol diet. Med. J. Nutrition Metab., 10:1-12.

Allain, C.C., Poon, L.S., Chan, C.S.G., Richmond, W. and Fu, P.C. (1974). Enzymatic determination of total serum cholesterol. Clin. Chem., 20: 470-475.

Allen, S.J., Martinez, E.G., Gregorio, G.V. and Dans, L.F. (2010). Probiotics for treating acute infectious diarrhea. Cochrane Database Syst. Rev., 10: CD003048.

Angelov, A., Gotcheva, V., Kuncheva, R. and Hristozova, T. (2006). Development of a new oat-based probiotics drink. Int J Food Microbiol., 112: 75 - 80.

Arkkila, P.E., Koskinen, P.J., and Kantola, I.M. (2001). Diabetic complications are associated with liver enzyme activities in people with type I diabetes. Diabetes Res Clin Pract., 52: 113-118.

Balku, B., Hu, G., Qiao, Q., Tuomilehto, J., Borch-Johnsen, K. and Pyoraja, K. (2004). Prediction of the Risk of Cardiovascular Mortality Using a Score that Includes Glucose as a risk factor. The DECODE study. Diabetologia, 47: 2118-2128.

Bancroft, J.D. and Stevens, A. (1996). The haematoxylin and eosin. Theory and practice of histological techniques. 4th ed, Ch 6, pp.99-112. Churchill Livingstone, London, New York \& Tokyo.

Baroutkoub, A., Mehdi, R.Z., Beglarian, R., Hassan, J., Zahra, S., Mohammad, M.S. and Hadis, E.M. (2010). Effects of probiotic yoghurt consumption on the serum cholesterol levels in hypercholestromic cases in Shiraz, Southern Iran. Sci. Res. Essays, 5: 2206-2209.

Batista, A.L., Silva, R., Cappato, L.P., Almada, C.N., Garcia, R.K., Silva, M.C. et al., (2015). Quality parameters of probiotic yogurt added to glucose oxidase compared to commercial products through microbiological, physical-chemical and metabolic activity analyses. Food Res. Int., 77: 627-635.

Beerens, H., (1990). An elective and selective isolation medium for Bifidobacterium spp. Lett. Appl. Microbiol., 11: 155 - 157.

Begley, M., Hill, C. and Gahan, C. (2006). Bile Salt Hydrolase Activity in Probiotics. Appl Environ Micobiol., 72: 1729-38.

Bekers, M., Marauska, M., Laukevics, J., Grube, M., Vigants, A., Karklina, D., Skudra, L., Viesturs, U. (2001). Oats and Fat-Free Milk Based Functional Food Product, Food Biotechnology 15 (1): 1-12.
Bekers, M., Marauska, M., Laukevics, J., Grube, M., Vigants, A., Karklina, D., Skudra, L. and Viesturs, U. (2001). Oats and Fat-Free Milk Based Functional Food Product. Food Biotechnol., 15: 1-12.

Bibiloni, R., Fedorak, R.N., Tannock, G.W., Madsen, K.L., Gionchetti, P., Campieri, M., De Simone, C. and Sartor, R.B. (2005). VSL\# 3 probiotic-mixture induces remission in patients with active ulcerative colitis. Am. J. Gastroenterol., 100: 1539 - 46.

Bruckert, E., (2006). Epidemiology of low HDL-cholesterol: results of studies and surveys. Eur Heart J. Suppl., 8:17-22.

Chapman, D.G., Gastilla, R. and Campbell, J.A. (1959). Evaluation of protein in food I.A. Method for the determination of protein efficiency ratio. Can. J .BiochemPhysiol, 37:679-86. Trinder, P., (1969). Determination of blood glucose using an oxidaseperoxidase system with a non-carcinogenic chromogen. J ClinPathol., 22:158-61.

Cummings, J.H. and Macfarlane, G.T. (1991). The control and consequences of bacterial fermentation in the human colon. J ApplBacteriol., 70:443-59.

De Man, J.C., Rogosa, M. and Sharpe, M.E. (1960). A medium for the cultivation of lactobacilli. J ApplMicrobiol., 23:130-135.

Deswal, A., Deora, N.S. and Mishra, H.N. (2014). Optimization of Enzymatic Production Process of Oat Milk Using Response Surface Methodology. Food Bioprocess Technol., 7: 610-618.

Dong, J., Cai, F., Shen, R. and Liu, Y. (2011). Hypoglycaemic effects and inhibitory effect on intestinal disaccharidases of oat beta-glucan in streptozotocin-induced diabetic mice. Food Chem. 129: 1066-1071.

Fanigliulo, L., Comparato, G., Aragena, G., Cavallaro, L., Iori, V., Miono, M., et al., (2006). Role of gut microflora and probiotic effects in the Irritable bowel syndrome. ActaBiomed., 77: 85 - 9 .

FAO/WHO (2002). Guidelines for the evaluation of probiotics in Food; Report of a joint Food and Agriculture Organisation of the United Nations/World Health Organisation Working Group on Drafting guidelines for the evaluation of probiotics in food: London, Ontario, Canada.

Felley, C.P., Corthésy-Theulaz, I., . Rivero, J.L, Sipponen, P., Kaufmann, M., Bauerfeind, P., Wiesel, P.H., Brassart, D., Pfeifer, A., Blum ， A.L. and Michetti, P. (2001). Favorable effect of acidified milk (LC-1) on Helicobacter pylori gastritis in man. Eur. J. GastroenterolHepatol., 13: 25 - 9.

Fernandez-Garcia, E., McGregor, J.U. and Traylor, S. (1998). The Addition of Oat Fiber and Natural Alternative Sweeteners in the Manufacture of Plain Yogurt. J Dairy Sci., 81: 655-63.

Fossati, P. and Prencipe, L. (1982). Serum triglycerides determined colorimetrically with an enzyme that produces hydrogen peroxide. Clin Chem., 28: $2077-$ 2080.

Furrie, E., Macfarlane, S., Kennedy, A., Cummings, J.H., Walsh, S.V., O'neiland, D.A. and Macfarlane, G.T. (2005). Synbiotic therapy (Bifido bacteriumlongum/ Synergy 1) initiates resolution of inflammation in patients with active ulcerative colitis: a randomized controlled pilot trial. Gut., 54: 242-9. 
Grundy, M.M., Fardet, A., Tosh, S.M., Rich, G.T and Wilde, P.J. (2018). Processing of oat: the impact on oat's cholesterol lowering effect. Food Funct., 9: 13281343.

Guerin-Danan, C. and Andrieux, C. (1998). Nutritional and health benefits of fermented milks in young infants. Cahiers de nutrition et de diététique, 33: 384-9.

Gunness, P. and Gidley, M.J. (2010). Mechanisms underlying the cholesterol-lowering properties of soluble dietary fibre polysaccharides. Food Funct., $1: 149-55$

Guo, L., Tong, L.T., Liu, L., Zhong, K., Qiu, J. and Zhou, S. (2014). The cholesterol-lowering effects of oat varieties based on their difference in the composition of proteins and lipids. Lipids Health Dis., 13:182 186.

Hassan, N.S. and Emam, M.A. (2012). Protective Effect of Camel Milk and Ginkgo biloba Extract Against Alloxan-Induced Diabetes in Rats. J Diabetes Metab., 3: 231.

Ibrugger, S., Kristensen, M., Poulsen, M.W., Mikkelsen, M.S., Ejsing, J., Jespersen, B.M., et al., (2013). Extracted oat and barley beta-glucans do not affect cholesterol metabolism in young healthy adults. J Nutr., 143:1579-85.

Isa, S.A., Ibrahim, K.G. and Abubakar, I. (2013). Effect of Camel Milk's Supplementation on Serum Glucose Levels, Lipid Profile and Body Weight of AlloxanInduced Diabetic Rats. Nig. J. Basic Appl. Sci., 21: 187-191.

Jemai, H., Fki, I., Bouaziz, M., Bouallagui, Z., El Feki, A., Isoda, H. and Sayadi, S. (2008). Lipid lowering and antioxidant effects of hydroxytyrosol and its triacetylated derivative recovered from olive tree leaves in cholesterol-fed rats. J Agric Food Chem., $56: 2630-2636$.

Jenkins, A.L., Jenkins, D.J.A., Zdravkovic, U., Würsch, P. and Vuksan, V. (2002). Depression of the glycemic index by high levels of $\beta$-glucan fiber in two functional foods tested in type 2 diabetes. Eur J Clin Nutr., 56: 622-628.

Kalliomäki, M., Salminen, S., Arvilommi, H., Kero, P., Koskinenand, P. and Isolauri, E. (2001). Probiotics in primary prevention of atopic disease: a randomized placebo-controlled trial. Lancet., 357: $1076-1079$

Kim, B., Park, K.Y., Ji, Y., Park, S., Holzapfel, W. and Hyun, C.K. (2016). Protective effects of Lactobacillus rhamnosus GG against dyslipidemia in high-fat diet-induced obese mice. Biochem. Biophys. Res. Commun., 473: 530-536.

Kume, H., Okazaki, K. and Sasaki, H. (2006). Hepatoprotective effects of whey protein on Dgalactosamine-induce hepatitis and liver fibrosis in rats. Biosci Biotechnol Biochem., 70:1281-1285.

Lambo, A.M., Öste, R., Nyman, M.E.G.L. (2005). Dietary fiber in fermented oat and barley $\beta$-glucan rich concentrates, Food Chemistry 89, 283-293.

Larcan, A., Lambert, H., Laprevote-Heully, M.C. and Delorme, N. (1979). Light and electron microscopic study of hepatic lesions in thecourse of hyperlactatemia in diabetic patients. DiabeteMetab., $5,103-112$.

Lenzen, S. (2008). The mechanisms of alloxan-and streptozotocin-in-duced diabetes. Diabetologia, 51: 216-226.
Liong, M.T. and Shah, N.P. (2005). Bile salt deconjugation ability, bile salt hydrolase activity and cholesterol coprecipitation ability of lactobacilli strains. Int. Dairy J., 15: 391-398.

Lopez-Virella, M.F., Stone, P., Ellis, S. and Coltwell, J.A. (1977). Cholesterol determination in high density lipoproteins separated by three different methods. Clin Chem. 23: 882-884.

Lukic, L., Lalic, N.M., Rajkovic, N., Jotic, A., Lalic, K. and Milicic, T. (2014). Hypertension in obese type 2 diabetes patients is associated with increases in insulin resistance and IL-6 cytokine levels: Potential targets for an efficient preventive intervention. Int. J. Environ. Res. Public Health, 11: 3586-3598.

Lye, H.S, Kuan, C.Y, Ewe, J.A, Fung, W.Y and Liong, M.T. (2009). The improvement of hypertension by probiotics: effects on cholesterol, diabetes, renin and phytoesterogens. Int J Mol Sci., 10: 3755 - 75.

Martensson, O., Andersson, C., Andersson, K., Öste, R. and Holst, O. (2001). Formulation of an oat-based fermented product and its comparison with yoghurt. J. Sci. Food Agri., 81: 1314-1321.

Mattila-Sandholm, T., Myllärinen, P., Crittenden, R., Mogensen, G., Fondén, R., and Saarela, M. (2002). Technological challenges for future probiotic foods. Int Dairy J., 12, 173-182.

Mc-Comas, K.A. and Gilliand, S.E. (2003). Growth of Probiotic and Traditional Yogurt Cultures in Milk Supplemented with Whey Protein Hydrolysate. J Food Sci., 68: 2090-2095.

Minaiyan, M., Zolfaghari, B. and Kamal, A. (2011). Effect of hydroalcoholic and buthanolic extract of Cucumissativus seeds on blood glucose level of normal and streptozotocin-induced diabetic rats. Iran J Basic Med Sci., 14: 436-442.

Obi, G.C., Okogbue, C.O. and Nwajide, C.S. (2001). Evolution of the Enugu Cuesta: A tectonically driven erosional process: Global Journal of Pure Applied Sciences., vol. 7, 321-330.

Othman, R.A., Moghadasian, M.H. and Jones, P.J. (2011). Cholesterol-lowering effects of oat b-glucan. Nutr Rev., 69: 299 - 309 .

Pei, R., Martin, D.A., DiMarco, D.M. and Bolling, B.W. (2017). Evidence for the effects of yogurt on gut health and obesity. Crit Rev Food Sci Nutr., 57:1569-1583.

Pereira, D. and Gibson, G. (2002). Effects of consumption of probiotics and prebiotics on serum lipid levels in humans. Crit. Rev. Biochem. Mol. Biol., 37: 259281.

Peschke, E., (2007). Melatonin, endocrine pancreas and diabetes. J. Pineal Res., 44: 26-40.

Prantera, C., Scribano, M.L., Falasco, G., Andreoli, A. and Luzi, C. (2002). Ineffectiveness of probiotics in preventing recurrence after curative resection for Crohn's disease: a randomized controlled trial with Lactobacillus GG. Gut., 51:405-409.

Radhika, S., Smila, K.H. and Muthezhilan, R. (2011). Antidiabetic and hypolipidemic activity of Punicagranatum Linn on alloxan induced rats. World J. Medical Sci., 6: 178-182.

Regand, A., Tosh, S.M., Wolever, T.M. and Wood, P.J. (2009). Physicochemical properties of beta-glucan in differently processed oat foods influence glycemic response. J. Agric. Food Chem. 57: 8831-8838. 
Reid, G., Bruce, A.W., Fraser, N., Heinemann, C., Owen, J. and Henning, B. (2001). Oral probiotics can resolve urogenital infections. FEMS Immunol. Med. Microbiol., 30: 49 - 52.

Roberfroid, M. (2002). Functional food concept and its application to prebiotics. Dig. Liver Dis., 34: S105S110.

Sadiq-Butt, M., Tahir-Nadeem, M., Khan, M.K., Shabirand, R. and Butt, M.S. (2008). Oat: unique among the cereals. Eur J Nutr., 47:68-79.

Saikali, J., Picard, C., Freitas, M. and Holt, P.R. (2004). Fermented Milks, Probiotic Cultures, and Colon Cancer. Nutr. Cancer., 49:14 - 24.

Sangwan, S. and Singh, R. (2018). Synergistic effect of oats and LGG fermented milk on lowering hypercholesterolemia in rats. J. Cereal Sci.,82: $164-$ 169.

SAS Institute (1999). Statistical Analysis system. SAS user's guide: for personal computers, version 8.2 Edition SAS Instintute, Cary, N.C.

Schermer, S. and Chermer, S. (1967). The Blood Morphology of Laboratory Animals, 3 (1967): The Blood Morphology of Laboratory Animals, $3^{\text {rd }}$ ed., F. A. Davis ed., F. A. Davis Company. Philadelphia. pp. 5-24.

Shehata, M.M.E.M. and Moussa, E.A. (2014). Evaluation of Therapeutic Efficiency of Camel Milk on Alloxaninduced Diabetic Rats. Journal of American Science, 10: $53-60$.

Sherwin, J.E., (1984). Liver function. In: kaplan LA, PESCE AJ, eds. Clinical chemistry, theory, analysis, and correlation. St. louis: mosby; 420- 438.

Sheth, A.A.and Garcia-Tsao, G. (2008). Probiotics and liver disease. J. Clin. Gastroenterol., 42: S80 - S84.

Shori, A.B. and Baba, A.S. (2011). Antioxidant activity and inhibition of key enzymes linked to type-2 diabetes and hypertension by Azadirachtaindica-yoghurt. J. Saudi Chem Soc. 17: 295-301.

St-Onge, M.P., Farnworth, E.R. and Jones, P.J. (2000). Consumption of fermented and nonfermented dairy products: effects on cholesterol concentrations and metabolism. Am J ClinNutr., 71:674-681.

Su, N., Li, J., Yang, L., Hou, G. and Ye, M. (2018). Hypoglycemic and hypolipidemic effects of fermented milks with added roselle (Hibiscus sabdariffa L.) extract. J Funct Foods, 43: 234-241.
Sudha, M.R., Chauhan, P., Dixit, K., Babu, S. and Jamil, K. (2009). Probiotics as complementary therapy for hypercholesterolemia. Biol. Med., 1: 1-13.

Szkudelski, T., (2001). Mechanism of alloxan and streptozotocin action in beta cells of the rat pancreas. Physiol. Res. 50: 537-546.

Tameda, M., Shiraki, K., Ooi, K., Takase, K., Kosaka, Y., Nobori, T. et al., (2005). Aspartate aminotransferaseimmunoglobulin complexes in patients with chronic liver disease. World J Gastroenterol., 11(10): 1529 1531.

Tiwari, U. and Cummins, E. (2011). Meta-analysis of the effect of b-glucan intake on blood cholesterol and glucose levels. Nutrition, 27: $1008-1016$.

Tomimatsu, T. and Horie, T. (2005). Enhanced glucose absorption in the rat small intestine following repeated doses of 5-fluorouracil. Chem. Biol. Interact., 155:129-139.

Tosh, S.M., (2013). Review of human studies investigating the post-prandial blood-glucose lowering ability of oat and barley food products. Eur. J. Clin. Nutr., 67: 310-317.

Tyrberg, B., Andersson, A. and Borg, L.A. (2001). Species Differences in Susceptibility of Transplanted and Cultured Pancreatic Islets to the $\beta$-Cell Toxin Alloxan. General and Comparative Endocrinology, 122: 238-251.

Villani, F., Mauriello ,G., Pepe, O., Blaiotta ,G., Ercolini, D., Casaburi, A., Pennacchia, C,and Russo, F (2005). The SIQUALTECA project technology and probiotic characteristics of Lactobacillus and coagulate negative Staphylococcus strain as starter for fermented sausage manufacture. Italian J. Anim. Sci., 4(2): 498.

Wieland H. and Seidel, D. (1983). A simple method for the precipitation of low density lipoproteins. J Lipid Res., 24:904 - 909 .

Yajing, L.I., Minli, C., Hongzhuan, X. and Hu, F. (2012). Effects of Encapsulated Propolis on Blood Glycemic Control, Lipid Metabolism, and Insulin Resistance in Type 2 Diabetes Mellitus Rats. Evid. Based Complement. Alternat. Med., 2012: 1 - 8.

Yang, J.L., Kim. Y.H. , Lee, H.S., Lee, M.S. and Moon, Y.K. (2003). Barley beta-glucan lowers serum cholesterol based on the up-regulation of cholesterol 7alpha-hydroxylase activity and mRNA abundance in cholesterol-fed rats. J. Nutr. Sci. Vitaminol., 49: $381-7$.

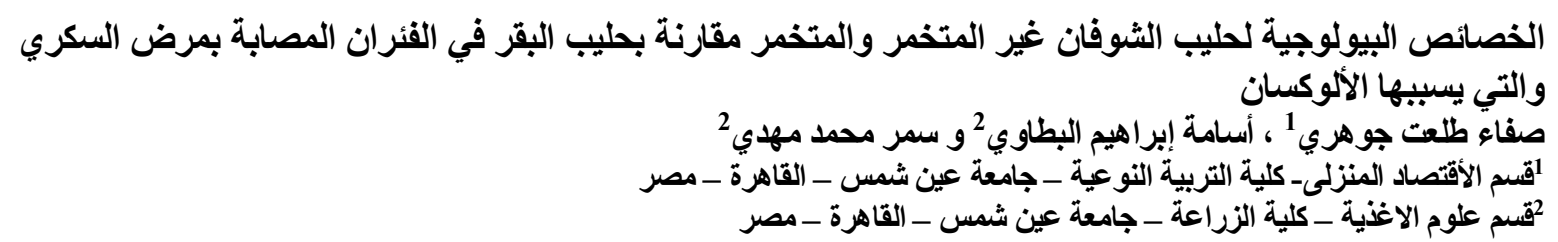

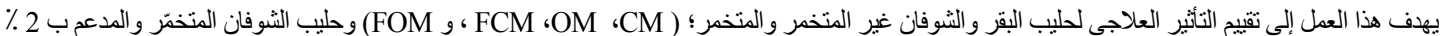

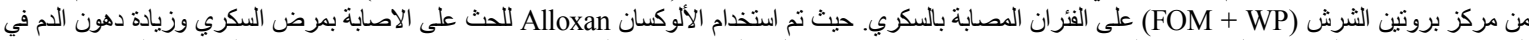

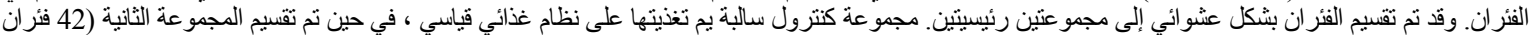

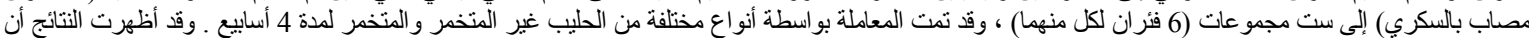

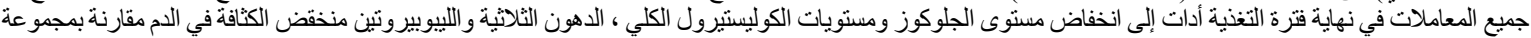

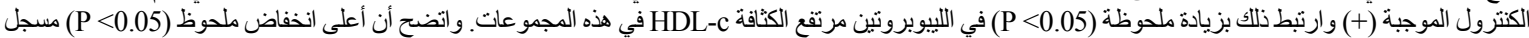

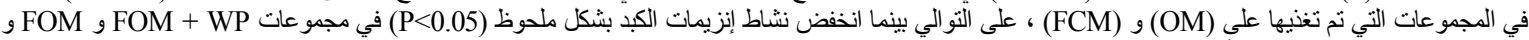

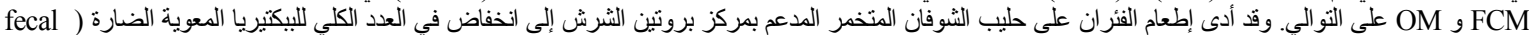

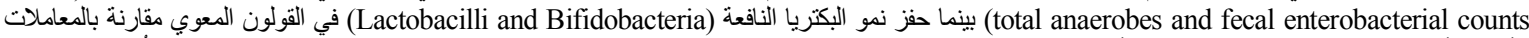

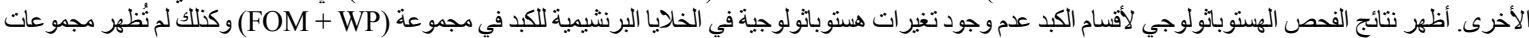

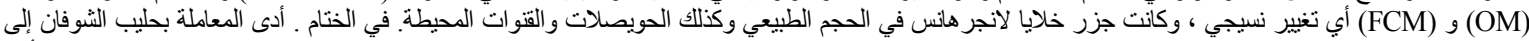

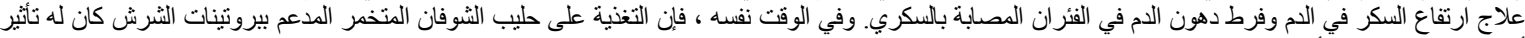
أفضل على الكبد كذلك تأثير ايجابي على تحفيز نمو البكتيريا المفيدة في القولوني. 